\title{
Analysis of Hygiene and Sanitation Practice Within Hospital Foodservice Employees. a Case Study in a Private Hospital in Yogyakarta
}

\author{
Oldriana Prawiro Hapsari*, Iman Permana**, Ekorini Listiowati*** \\ *Author Coresspondent: clairvoo@gmail.com \\ * Mater of Hospital Management, Universitas Muhammadiyah Yogyakarta, Indonesia \\ **Master of Nursing, Universitas Muhammadiyah Yogyakarta, Indonesia \\ *** Faculty of Healthy and Science, Universitas Muhammadiyah Yogyakarta, Indonesia
}

\begin{tabular}{l}
\hline I N D E X I N G \\
\hline Keywords: \\
Hygiene and sanitation; \\
Food Hygiene; \\
Hospital Foodservice
\end{tabular}

Kata kunci:

Kebersihan dan sanitasi,

Kebersihan makanan;

Layanan Makanan

Rumah Sakit;

\begin{abstract}
A B S T R A C T
Hospitals are expected to provide service according to accreditation comittee standard. One of the accreditation criteria is Infection and Prevention Control, in which hospital must minimalise infection risk from the provided facilities such as hospital food service. Analysing food handlers hygiene and sanitian practice in PKU Muhammadiyah Gamping Hospital's Food Service Unit. Research method is qualitative method, rand the design is a case study. Subjects of the research are 13 food handlers, one food service unit supervisor, one sanitation unit supervisor, one infection and prevention control unit supervisor. Here we conducted a questionnaire to measure knowledge, an observation check list to observe food handlers compliance, and an in-depth interview for their perspective on hygene and sanitation practice. Foodhandlers perspective in hygiene and sanitation practice, on knowledge wise $10(76,92 \%)$ foodhandlers have good knowledge on hygiene and sanitation. $13(100 \%)$ foodhandlers have good practice and complience on practicing food safety and hygiene and sanitation practice. The Conclusion and Advice there are some adversities such as neglection to wear personal protective equipments and some facilities needs to be upgraded.
\end{abstract}

Rumah sakit diharapkan dapat memberikan layanan sesuai standar akreditasi komite. Salah satu kriteria akreditasi adalah Pengendalian Infeksi dan Pencegahan, di mana rumah sakit harus meminimalkan risiko infeksi dari fasilitas yang disediakan seperti layanan makanan rumah sakit. Menganalisa penangan makanan kebersihan dan praktek sanitasi di Unit Layanan Makanan Rumah Sakit PKU Muhammadiyah Gamping. Metode penelitian adalah metode kualitatif, rand desain adalah studi kasus. Subjek penelitian ini adalah 13 penjamah makanan, satu pengawas unit layanan makanan, satu pengawas unit sanitasi, satu pengawas infeksi dan pengawas unit pencegahan. Di sini kami melakukan kuesioner untuk mengukur pengetahuan, daftar periksa observasi untuk mengamati kepatuhan penangan makanan, dan wawancara mendalam untuk perspektif mereka tentang praktik hygene dan sanitasi. Perspektif Foodhandlers dalam praktek kebersihan dan sanitasi, pada pengetahuan bijaksana 10 (76,92\%) foodhandlers memiliki pengetahuan yang baik tentang kebersihan dan sanitasi. 13 (100\%) penganiaya makanan memiliki praktik dan kepatuhan yang baik dalam mempraktekkan keamanan pangan dan praktik kebersihan dan sanitasi. Kesimpulan dan Saran ada beberapa kesengsaraan seperti kelalaian memakai alat pelindung diri dan beberapa fasilitas perlu ditingkatkan.

(C) 2018JMMR. All rights reserved

Article History: Received 2018-Aug-31; Revised 2018-Dec-04; Accepted 2018-Dec-08

\section{INTRODUCTION}

Hospitals are expected to provide service according to accreditation committee standards. One of the accreditation criteria is Infection and Prevention Control, in which the hospital must minimalize infection risk from the provided facilities such as the hospital food service. Said criteria consisting of kitchen sanitation and a good food manufacturing process, as well as engineering control to minimalise infection risk in hospital ${ }^{1}$. Food hygiene requirements should be practiced according to Ministry of
Health regulation, 1204/Menkes/KEP/X/2004 on Health Sanitation in a Hospital Environment. ${ }^{2}$

Research in Palembang BARI Hospital shows that only $52.7 \%$ of foodhandlers are practicing food hygiene and sanitation in the hospital foodservice unit. $\frac{3}{3}$ Research done in Moewardi Hospital shows a poor foodhandler personal hygiene handwash practice, with Staphylocccus sp found in their hand swap specimen. ${ }^{4}$

PKU Muhammadiyah Gamping Hospital Foodservice Unit doesn't do the cooking, only food portioning and 
serving the same applies to the drinks. Food saftey and food hygiene and sanitation are important in the hospital foodservice unit to prevent foodborne disease, related researches are needed to analyse foodhandlers' hygiene and sanitation practice in PKU Muhammadiyah Gamping Hospital, Sleman, Special Region of Yogyakarta and for evaluation and regulation purpose for said hospital in hygiene and sanitation practice.

\section{RESEARCH METHOD}

Our research method is a qualitative research and the research design is a case study. Subjects of the research are 13 food handlers, one food service unit supervisor, one sanitation unit supervisor and one infection and prevention control unit supervisor. Here we conducted a questionnaire to measure knowledge, an observation check list to observe foodhandlers, compliance, and an in-depth interview for their perspective on hygiene and sanitation practice.

\section{RESULT AND DISCUSSION}

PKU Muhammadiyah Gamping Hospital is a development of PKU Muhammadiyah Hospital in Yogyakarta. The PKU Muhammadiyah Gamping Nutrition Unit at the time of the research was being carried out in the process of being moved to a new building and currently only carried out the process of food processing. Every day the Nutrition Unit prepares breakfast, morning break, lunch, lunch intervals and dinner. The distribution is carried out by 13 people, divided into 2 shifts, namely morning afternoon (7 people), afternoon - evening shifts (6 people). 13 of these employees or implementing nutrition officers have a vocational / high school vocational education background.

Table 1. Research Subjects Characteristics

\begin{tabular}{llll}
\hline & Characteristics & N & \% \\
\hline 1 & Age & & \\
& $<30$ years old & 9 & 69.23 \\
& $31-40$ years old & 1 & 7.69 \\
& $41-50$ yeras old & 3 & 23.08 \\
2 & Gender & & \\
& Male & 1 & 7.69 \\
& Female & 12 & 92.31 \\
& Level of Education & & \\
& Pre-professional & & \\
\hline
\end{tabular}

Table 1. (Continued) Research Subjects Characteristics

\begin{tabular}{llll}
\hline & Characteristics & N & \% \\
\hline 3 & high school grad & 11 & 84.62 \\
& High School grad & 2 & 15.38 \\
4 & Position & & \\
& Executant 13 & 100.00 & \\
5 & Work experience & & \\
& $<5$ years & 8 & 61.54 \\
& $>5$ year & 5 & 38.46 \\
6 & Personnel Trainings & \\
& Yes & 10 & 76.92 \\
& No & 3 & 23.08 \\
& Total & 13 & 100 \\
\hline
\end{tabular}

There were 13 research subjects, all of them are hospital foodservice's staff. 12 of them are female, and 1 is a male. Level of education mostly are high school graduate and pre-professional high school graduate. Interviewees are hospital foodserbice unit's staff and supervisor, sanitation unit supervisor, and infection and prevention control unit supervisor.

Based on the cross tabulation table above, it is known that the majority of respondents are employees who are less than 30 years old and the least respondents are employees who are aged 31-40 years. The majority of respondents were female while male respondents were few. This shows that human resources in the nutrition sanitation section of the PKU Muhamadiyah Gamping Hospital are on average female. Knowledge of employee nurses about food hygiene and sanitation in PKU Muhammadiyah Gamping Hospital as many as 10 (76.92\%) employees had good knowledge.

Table 2. Cross Tabulation of Level of Knowledge and Personnel Trainings

\begin{tabular}{|c|c|c|c|}
\hline \multicolumn{4}{|c|}{ Level of Knowledge Personnel Trainings } \\
\hline Good & Less & Yes & No \\
\hline $\mathrm{N} \%$ & $\mathrm{~N} \%$ & $\mathrm{~N} \%$ & $\mathrm{~N} \%$ \\
\hline 10 & 3 & 10 & 3 \\
\hline 76,92 & 23,08 & 76,92 & 23,08 \\
\hline
\end{tabular}

Our research used questionnaire to measure level of knowledge and the result are 10 staff $(76,92 \%)$ have good knowledge. All 13 staff (100\%) are observing hygiene and sanitation practice during work process, from food portion processing, serving, distributing, personal hygiene, and waste management. 
Table 3. Observation Result of Staff's Compliance to Hygiene and Sanitation Practice

\begin{tabular}{|c|c|c|}
\hline Variable (s) & Yes & No \\
\hline & $\mathrm{N} \%$ & $\mathrm{~N} \%$ \\
\hline \multicolumn{3}{|l|}{ Serving and Distributing } \\
\hline Using food trolley & $12(100 \%) 0$ & \\
\hline $\begin{array}{l}\text { No serving } \\
\text { food stored }>24 \mathrm{hrs}\end{array}$ & $12(100 \%)$ & 0 \\
\hline $\begin{array}{l}\text { Food is served in covered } \\
\text { utensils }\end{array}$ & $12(100 \%)$ & 0 \\
\hline Good serving practices & $12(100 \%)$ & 0 \\
\hline \multicolumn{3}{|l|}{ Food Processing Area } \\
\hline Cleaning & $1(100 \%)$ & 0 \\
\hline $\begin{array}{l}\text { Dilengkapi dengan sungkup } \\
\text { dan cerobong asap }\end{array}$ & $1(100 \%)$ & 0 \\
\hline \multicolumn{3}{|l|}{ Foodhandlers } \\
\hline $\begin{array}{l}\text { Medical checkup } \\
\text { surveillance }\end{array}$ & $12(100 \%) 0$ & \\
\hline \multicolumn{3}{|c|}{ (no open wounds, dischrages, etc) } \\
\hline Wearing Personal Protective & $12(100 \%)$ & 0 \\
\hline \multicolumn{3}{|l|}{$\begin{array}{l}\text { Equipment during food } \\
\text { processing }\end{array}$} \\
\hline No direct contact to food & $12(100 \%)$ & 0 \\
\hline Good hygiene practice & $12(100 \%)$ & 0 \\
\hline \multicolumn{3}{|l|}{ Waste Disposal } \\
\hline \multicolumn{3}{|l|}{ Recycled waste } \\
\hline Organic or unorganic $1(100 \%)$ & 0 & \\
\hline \multicolumn{3}{|l|}{ Garbage Bin } \\
\hline Lightweight & $1(100 \%)$ & 0 \\
\hline Black plastic bag & $1(100 \%)$ & 0 \\
\hline \multicolumn{3}{|c|}{ labelled with domestic in white letter } \\
\hline \multicolumn{3}{|c|}{ Pest Control, Waste Storage and Disposal } \\
\hline Pest Control once a month & $1(100 \%)$ & 0 \\
\hline $\begin{array}{l}\text { Waste disposal max } 3 \times 24 \mathrm{hrs} \\
\text { Using trolley }\end{array}$ & $1(100 \%)$ & 0 \\
\hline
\end{tabular}

\section{Knowing foodhandlers' perspective on food hygiene and} sanitation practice

Foodhandlers, accoring to Health Ministry of Republic of Indonesia, are people who have direct contact with food and cooking utensils, from preparation process, cleaning, processing, distributing, and serving. Foodhandlers have a major role in transmitting disease during processing food material. There are many factors regarding food safety in food processing, such as food material procurement, food processing material, and serving food.

Research result of the questionnaire to measure knowledge of the foodlhanders: $10(76.92 \%)$ foodhandlers have good knowledge on hygiene and sanitation practice, while the other 3 (28.03\%) have lesser knowledge. Lidya (2011) conducted research in Demak State Hospital in which $48.5 \%$ of foodhandlers have good hygiene and sanitation practice. One of the affecting factors in good knowledge is level of education, in which our subjects' level of education are mostly high school graduate (84.62\%), and $15.38 \%$ are vocational and pre-professional high school graduates. These level of education are considered good enough.

\begin{tabular}{cccc}
\hline \multicolumn{4}{c}{ Level of Personnel Trainings Knowledge } \\
\hline Good & Less & Yes & No \\
N\% & N\% & N\% & N\% \\
10 & 3 & 10 & 3 \\
76,92 & 23,08 & 76,92 & 23,08 \\
\hline
\end{tabular}

Inayah (2015) stated that level of education is one of the factors affecting level of knowledge, because information is one of the many sources of knowledge. ${ }^{5}$ The higher the education, the more informtion someone can get, hence more knowledge someone might gain. Nevertheless, a lower level of education doesn't necessarily mean lesser knowledge, because school isnt the only way to gain information and knowledge.

Beside level of education, foodhandlers are aware that standard operating procedure, socialisation and briefing affect good knowledge and good practice. This socialisation will give information and knowledge, which form good food hygiene practices. Abdullah (2016) stated that hygiene and sanitation training results in an increased percentage of foodhandlers with good knowledge to $20.68 \%$, leaving those with average knowledge at $79.31 \%$, and decreasing foodhandlers with less knowledge than acceptable to $0 \%$. This research done in regards to the percentage of foodhandlers with lesser knowledge and with work orientation, in which there is standard operating procedure socialisation, evaluation system, done from other units such as Infection; and Prevention Control. The lesser knowledge didn't affect foodhandlers compliance on hygiene and sanitation practices. $100 \%$ of them have good hygiene and sanitation practices.

We conclude the foodhandlers' perspective on practicing good food hygiene and sanitation based on the questionnaire and our observation. There are few factors shaping foodhandlers' perspective and knowledge, in which they get from the procedures socialisation and work experiences. Employees or foodhandlers must understand more about food hygiene and sanitation practices by attending hospitals procedure socialisation, or by many 
medias regarding food hygiene and sanitation, alternatively they can actively looking for a source which can help.

\section{Knowing management's perspective on food hygiene and sanitation practice}

One of many factors supporting patients health is hospital foodservice. According to Ministry of Health (2013), hospital foodservice is a process started from menu planning, to food serving, to patients. Management's roles are to manage and evaluate the service. Good foodservice management means good provision. ${ }^{?}$

Based on the in depth interview, we conclude that management has good perspective in food hygiene and sanitation practice in PKU Muhammadiyah Gamping Hospital's foodservice. Management, the supervisors we interviewed, know each of their roles in supporting the foodservice unit, and how the hygiene and sanitaion practice is done, as well as how a third party helps. Besides monitoring and evaluating, management also plans employees' training.

Training and workshop correlates with hygiene pratice. These trainings and workshops are essential for the employees or foodhandlers to do basic hygiene and sanitation practice. Foodhandlers must be dedicated and be professional in understanding institution's policy. Trainings and workshops must be held periodically so that foodhandlers are able to maintain food safety practices and food hygiene sanitation practices as well as personal hygiene.

It's important as well to maintain a relationship with other parties to the support foodservice unit, such as the sanitation unit for clean water, the Health Department for bacterial examination, tools calibration, and collaboration with Infection and Prevention Control it help to enhance food hygiene and sanitation practices. Besides monitoring, Infection and Prevention Control also evaluates foodhandlers' hygiene and sanitation practices so that they can correct the practice according to standard operating procedures.

Management must maintain good performance of foodhandlers hygiene and sanitaion practices hence evaluations are done a few times a year and the foodhandlers as well as every employee in the hospital has to do their training in basic infection and prevention control and work safety too.

\section{Knowing foodservice compliance on practicing standard} procedures
Food hygiene is needed to ensure good food manufactoring and production practice and in prerequisite practice is defined as the basic conditions and activities necessary to maintain a hygienic environment throughout the food chain suitable for the production, handling and provision of safe end products and food that is safe for human consumption. - Foodhandlers also need to maiantin personal hygiene and a good sanitation practice to minimalise cross contamination when handling food. ${ }^{-}$

There are few important aspects in the food hygiene and sanitation practice, those are serving and distributing food, food processing unit, foodhandlers, drainage and waste management, and management of raw materials. Observation result of foodhandlers compliance resulted in $13(100 \%)$ of foodhandlers practicing good food hygiene and sanitation. Few affecting factors are their motivation, good hygiene facilities, training and evaluation system.

Some of the motivations are self awareness to practice personal hygiene, which goes hand in hand with standard procedures. The in depth interview showed that a majority of the foodhandlers have the self awareness to practice personal and food hygiene. There's correlation between self motivation and perspective with nurses' compliance to standard procedures.

Beside motivation, training also has an important role in affecting employees' comliance to standard procedures. 10 foodhandlers $(76,92 \%)$ have done staff training in hygiene and sanitation practices and work safety while the other $3(23,08 \%)$ haven't. Similar to other research by Susanti (2011), most of the research subjects $(63,2 \%)$ have done training. Purpose of trainings are to bring awareness to the staff about food hygiene and sanitation practices. . $^{10}$ Staff members who are aware will perform according to standard procedures.

All research subjects (100\%) showed good compliance towards standard procedures despite 3 foodhandlers $(23,08 \%)$ having lesser kowledge and 3 foodhandlers $(23,08 \%)$ having not done hygiene and sanitation training. Those didnt affect the staff's performance because of a good management system, such as work orientation, monitoring and an evaluation system which is done routinely. Good attitude and habit contribute in personal hygiene awareness, which also can be done by training and some media such as posters, flyers and banners in a work environment ${ }^{11,12}$. PKU Muhammadiyah Gamping Foodservice Unit only have a few posters containing food and personal hygiene information. 


\section{Knowing staff's adversities on practicing standard procedures.}

Staff have been practicing standard procedures in PKU Muhammadiyah Gamping Hospital and it has positive effect in their performance. Although, our research resulted in a few adversities, such as staff negligance to wear personal protective equipment, and some facilities needing to be upgraded. These adversities must be addressed properly so that staff can practice better hygiene.

Good food hygiene practice is a basic principle in the foodservice of a hospital, because this foodservice is to provide food for patients in which there is plenty potential for cross contamination. Good food hygiene practice correlates with foodhandlers' knowledge, attitude, and compliance towards standard procedures and personal hygiene. $\frac{10}{}$ Therefore, neglogance to wear personal protective equipment might be caused by a lack of knwoledge and or work experiences.

There are foodhandlers in PKU Muhammadiyah Gamping Hospitals whom have been employed for more than 5 years, they consist of 8 staff members (61.54\%). These members which have been employed for longer periods of time tends to have more knowledge compared to those with less than 5 years work experience. stated that $68.4 \%$ staff with 5 years working experience have good knowledge regarding their work. $\frac{10}{}$

Facilities which need to be upgraded also cause adversity in regards to staff's hygiene and sanitation practice. Good facilities is a requirement for them to practice good hygiene and sanitation, especially the provision of clean water, providing personal hygiene facilities (cloakrooms, sanitary facilities, hand-washing facilities $)^{7}$.

Evaluation and follow ups need to be done to all foodhandlers, for a better hygiene and sanitation practice and in personal protective equipment wearing, as well as policy or standard operating procedures regarding personal hygiene.

\section{CONCLUSION}

Staffs perspective on hygiene and sanitation practice, knowledge wise, $10(76.92 \%)$ staff members have good knowledge. Level of education is one of many factors affecting knowledge. Self awareness in attending procedure socialisation and briefing contribute to good food hygiene.

Management has good perspective on employees' hygiene and santitaion practice. Supervisors know each other unit's role in supporting good food hygiene practice and foodservice unit itself, as well as how third parties help better food hygiene practice.

Staff showing good compliance towards standard procedure with 13 staff (100\%) practicing good food hygiene according to standard procedure. Some affceting factors are staff personal motivation and personnel trainings.

Adversities found are negligance on wearing personal protective equipment and facities which need to be upgraded. Evaluation and follow ups need to be done to all foodhandlers, for better hygiene and sanitation practice and in personal protective equipments wearing, and more policy or standard operating procedures regarding personal hygiene.

\section{REFERENCE}

1. Komite Akreditasi Rumah Sakit. 2012. Instrumen Akreditasi Rumah Sakit Standar Akreditasi Rumah Sakit versi 2012 Edisi 9-1

2. Kementrian Kesehatan RI. 2013. Pedoman Pelayanan Gizi Rumah Sakit. Dirjen Bina Upaya Kesehatan, Jakarta.

3. Andriani, Mewi. Zaman, Chairil. Malaka, Tan. 2010. Analisis Aplikasi Higiene Sanitasi Makanan di Instalasi Gizi Rumah Sakit Umum Daerah Palembang Bari Tahun 2009. Jurnal Kesehatan Bina Husada, Vol 6 No 2.

4. Asmoro, Apri Atok Puji. 2008. Hubungan Kebersihan Tangan Dengan Keberadaan Bakteri Staphylococcus Pada Penjamah Makanan Di Instalasi Gizi Rumah Sakit dr.Moewardi. Universitas Diponegoro, Semarang.

5. Inayah. 2015. Hubungan Pengetahuan Higiene Dan Sanitasi Makanan Terhadap Sikap Dan Perilaku Penjamah Makanan Di Kantin Universitas Tanjungpura. Naskah Publikasi: Universitas Tanjungpura Pontianak

6. Abdullah, Faisal. 2016. Efektivitas Penyuluhan Higiene Dan Sanitasi Terhadap Peningkatan Pengetahuan, Sikap Dan Perilaku Penjamah Makanan Di Kantin Yang Dikelola Universitas Tanjungpura Pontianak. Naskah Publikasi: Universitas Tanjungpura Pontianak

7. Rindjani, Tia. 2016. Pengetahuan Dan Praktek Higiene, Sanitasi, \& Keselamatan Kerja Serta Produktivitas Tenaga Pengolah Makanan Di Pondok Pesantren. Skripsi : ITB Bogor 
8. Schiffer, B, Samb, B, \& Knops, J, 2011, Principles of higiene and food safety management, PIP c/o COLEACP, Brussels. https://www.sustainabilityxchange.info/filesagri/COL EACP_PIP_Training\%20Manual_1.compressed.pdf

9. Rahmadhani. Sumarmi. 2017. Gambaran Penerapan Prinsip Higiene Sanitasi Makanan Di PT Aerofood Indonesia, Tangerang, Banten. Research Study Amerta Nutr (2017) 291-299 291 DOI : 10.2473/amnt.v1i4.2017.291-299

10. Susanti, Hendrawati dan Montain. 2011. Profil Kepatuhan Higiene Perorangan Penjamah Makanan di Instalasi Gizi dan Tata Boga Rumah Sakit Penyakit Infeksi (RSPI) Prof. Dr. Sulianti Saroso. The Indonesian Journal of Infectious Disease.

11. Purnama, Angga. 2012. Kasus Keracunan Massal di Bayat Makanan Mengandung Bakteri. Joglosemar. [Online] http://edisicetak.joglosemar.co/berita/kasuskeracunan-massal-di-bayat-makanan-mengandungbakteri-107301.html diakses pada 22 September 2017 pukul 10.05 WIB.

12. Mirawati, Sitorus dan Hasyim. 2011. Analisis Personal Hygiene Dan Food Handling Pada Penyelenggaraan Makanan Pasien Di RSUP Dr. Mohammad Hoesin Palembang. Jurnal Ilmu Kesehatan Masyarakat Volume 2 Nomor 01 Maret 2011 